Abstracta Iranica Abstracta Iranica

Revue bibliographique pour le domaine irano-aryen

Volume 34-35-36 | 2017

Comptes rendus des publications de 2011-2013

\title{
Amy Landau. Visibly foreign, visibly female: The eroticization of zan-e farangi in seventeenth-century Persian painting
}

Isabelle Imbert

\section{(2) OpenEdition \\ Journals}

Édition électronique

URL : http://journals.openedition.org/abstractairanica/41241

DOI : 10.4000/abstractairanica.41241

ISSN : 1961-960X

Éditeur :

CNRS (UMR 7528 Mondes iraniens et indiens), Éditions de l'IFRI

Référence électronique

Isabelle Imbert, « Amy Landau. Visibly foreign, visibly female: The eroticization of zan-e farangi in seventeenth-century Persian painting », Abstracta Iranica [En ligne], Volume 34-35-36 | 2017, document 3, mis en ligne le 15 juillet 2016, consulté le 02 octobre 2020. URL : http://journals.openedition.org/ abstractairanica/41241; DOI : https://doi.org/10.4000/abstractairanica.41241

Ce document a été généré automatiquement le 2 octobre 2020.

Tous droits réservés 


\section{Amy Landau. Visibly foreign, visibly female: The eroticization of zan-e farangi in seventeenth-century Persian painting}

Isabelle Imbert

\section{RÉFÉRENCE}

Amy Landau. « Visibly foreign, visibly female: The eroticization of zan-e farangi in seventeenth-century Persian painting ", in : F. Leoni and M. Natif, eds., Eros and sexuality in Islamic Art. Farnham, Ashgate, 2013, p. 99-130.

A. Landau s'intéresse ici la figure féminine européenne dans la peinture persane du XVII ${ }^{e}$ siècle. L'article revient dans un premier temps sur les prémices de l'érotisation de l'Européenne par les artistes et crée un parallèle intéressant avec les figures érotiques de la poésie persane. Dans un second temps, l'A. analyse différentes sources iconographiques prenant part à la construction de la figure féminine sensuelle et exotique. Sont ainsi passées en revue plusieurs peintures de Moḥammad Zamān, mises en relation avec des portraits européens de femmes. Enfin, l'étude se termine par une ouverture sur de nouvelles pistes de recherche concernant le transfert du désir à un Autre européen et fait notamment le parallèle avec les périodes postérieures, jusqu'au XIXe s. qājār. 


\section{AUTEURS}

\section{ISABELLE IMBERT}

Université Paris-Sorbonne 